\title{
METODE MENABUNG PERSPEKTIF ZAMAN NABI YUSUF AS.
}

\author{
Agung Mandiro Cahyono \\ Institut Agama Islam Pangeran Diponegoro Nganjuk \\ mandiroagung@gmail.com
}

\begin{abstract}
Saving is an activity to prepare future costs so that all the necessities of life remain stable and orderly. Mental preparation before saving is to be frugal. Without this it is very difficult to save. Various methods of saving, including saving at home, saving in the bank. The author examines the method of saving the number of perspectives in the time of the Prophet Joseph (as). that is, setting aside more of the earth's savings than allocating consumptive needs. As a result, when a famine occurs / economic crisis, the savings can meet the conditions of a famine that are met in a stable and orderly manner. Saving for 7 years, the savings can meet the needs for the next 7 years during famine. Writing this with the literature method, which uses the approach of interpretive studies and then analyzed and applied in the present age. The results of the analysis that the theory of saving is a quota of more savings the money from income than expenditure.
\end{abstract}

Keywords: Saving, Age of the Prophet Joseph

\section{A. Pendahuluan}

Menabung merupakan bagian dari mempersiapkan perencanaan masa yang akan datang sekaligus untuk menghadapi hal-hal yang tidak diinginkan. Secara teknis, cara menabung yaitu menyisihkan harta yang dimiliki saat ini untuk memenuhi kebutuhan masa depan. Para pakar keuangan sering kali mengatakan bahwa cara terbijak untuk menabung yaitu mengambil di muka sebesar 10\% - 20\% dari pendapatan. Berarti uang yang disimpan bukanlah sisa dari konsumsi, melainkan alokasi terencana di muka karena diambilkan sebelum pemenuhan kebutuhan konsumsi. ${ }^{1}$ Islam melarang konsumsi yang berlebihan dan penimbunan kekayaan, karenanya dana perlu diorganisasi dengan cara yang baik agar terus berkembang dan

\footnotetext{
${ }^{1}$ Dwi Suwikyo, Ayat-Ayat Ekonomi, (Yogyakarta: Pustaka Pelajar, 2010), 176
} 
berkelanjutan. Aset tidak akan habis dikonsumsi tetapi harus ditabung atau diinvestasikan. $^{2}$

Untuk pengeluaran yang bersifat konsumtif, yang dinamakan nafkah, Ibnu Sina berpendapat bahwa yang termasuk segala belanja untuk kebutuhan hidup manusia terutama makan, tempat tinggal, belanja rumah tangga, belanja untuk istri, dan belanja untuk anak. Karena macamnya banyak sekali dan mempunyai ukuran berbeda-beda, Ibnu Sina menganjurkan supaya dalam semua belanja konsutif itu harus hemat dan sederhana, tidak berlebihan dan pula berkekurangan. Adapun ukuran untuk menetapkan sederhana dan hemat itu ialah pendapat umum. Akan tetapi ada pula perbelanjaan yang mempunyai ukuran tersendiri yang tidak dapat menggunakan ukuran pendapat umum. Dalam hal ini dianjurkan supaya memakai pertimbangan sendiri yang sehat dengan tetap berpegang pada prinsip sederhana dan hemat. ${ }^{3}$

\section{B. Lembaga Keuangan}

Lembaga keuangan adalah badan usaha yang bergerak dibidang keuangan yang bertugas untuk mengumpulkan aset dalam bentuk dana dari masyarakat dan menyalurkannya kembali kepada masyarakat. Beberapa lembaga (institusi) atau perantara pasar keuangan yang ada di Indonesia yaitu:

1. Lembaga keuangan bank

Bank merupakan lembaga keuangan yang menawarkan baik jasa simpanan, pinjaman (kredit) atau jasa keuangan lainnya yang dapat dilayani oleh bank umum (komersil) maupun bank perkreditan rakyat (BPR). Jenis bank dilihat dari segi mencari keuntungan dewasa ini terdiri dari bank yang beroperasi berdasarkan prinsip konvensional (barat) dan syariah (Islam). Bank menyediakan berbagai produk

${ }^{2}$ Ilfi Nur Diana, Hadis-Hadis Ekonomi, (Malang: UIN Maliki Press, 2012), 117

${ }^{3}$ Abdullah Zaky Al Kaaf, Ekonomi Dalam Perspektif Islam, (Bandung: CV Pustaka Setia, 2002), 184 
keuangan, baik dalam bentuk simpanan (rekening), pinjaman (kredit), valuta asing, maupun jasa keuangan lainnya, baik yang bersifat jangka pendek, maupun jangka panjang. Bahkan perbankan juga dapat menjadi perantara antara lembaga keuangan untuk melakukan transaksi keuangan. Fungsi bank antara lain:

a. Agent of trust yaitu lembaga yang landasannya adalah kepercayaan.

b. Agent of development yaitu lembaga yang memobilisasi dana untuk pembangunan ekonomi.

c. Agent of service yaitu lembaga yang memobilisasi jasa untuk pembangunan ekonomi. Jasa ini antara lain dapat berupa jasa-jasa pengiriman uang, penitipan barang berharga, pemberian jaminan bank dan penyelesaian tagihan.

2. Bursa efek

Bursa efek, merupakan tempat diperjualbelikannya modal jangka panjang seperti saham dan obligasi. Dalam bursa efek terdiri dari dua pasar, yaitu pasar primer (primery market) dan pasar sekunder (secondary market). Pasar primer yaitu pasar yang menangani pertama kali emisi sekuritas suatu perusahaan. Pasar sekunder yaitu pasar yang melayani sehari-hari transaksi perdagangan sekuritas yang telah beredar, setelah masa penjualan pasar primer berakhir.

3. Asuransi

Asuransi merupakan usaha pertanggungan terhadap suatu resiko yang akan terjadi. Pertangguangan ini terdiri dari perusahaan asuransi sebagai penanggung dengan nasabah sebagai tertanggung. Perusahaan asuransi menerima premi yang dibayarkan oleh tertanggung dan apabila tertanggung menderita kerugian seperti yang telah diperjanjikan, maka perusahaan asuransi sebagai penanggung akan menggantikannya. Perusahaan asuransi juga memberikan asuransi untuk beasiswa di mana nasabah penyetor sejumlah uang dan uang tersebut dapat diambil setelah jangka waktu tertentu. Dana yang terkumpul di perusahaan asuransi biasanya diinvestasikan kembali bagi pihak-pihak yang membutuhkan.

4. Dana pensiun 
Dana pensiun, merupakan perusahaan yang memungut dana bagi karyawan suatu perusahaan. Artinya perusahaan memotong dana (gaji karyawan suatu perusahaan) dengan jumlah tertentu yang kemudian disetorkan ke perusahaan dana pensiun. Dana yang terkumpul oleh perusahaan digunakan atau diinvestasikan kembali. Setelah memasuki pensiun, maka perusahaan dana pensiun di karyawan dapat mengambil uangnya kembali sesuai perjanjian yang telah dibuat. ${ }^{4}$

\section{Peranan Uang}

Merujuk kepada Mu'jam Al-Muhfaras (Kamus Al-Quran) oleh Fuad Abdul Baqi, kata mal (uang) terulang dalam Al-Quran sebanyak 25 kali (dalam bentuk tunggal) dan amwal (dalam bentuk jamak) sebanyak enam puluh satu kali. Diamati oleh Hassan Hanafi sebagaimana dikemukakan dalam bukunya Ad-Din wa Ats-Tsaurah bahwa kata tersebut mempunyni dua bentuk.

Pertama, tidak dinisbahkan kepada "pemilik", dalam arti dia berdiri sendiri. Ini menurutnya adalah sesuatu yang logis karena memang ada harta yang tidak menjadi objek kegiatan manusia, tetapi berpotensi untuk itu. Kedua, dinisbahkan kepada sesuatu, seperti "harta mereka", harta anak-anak yatim, "harta kamu" dan 1ain-1ain. Ini adalah harta yang menjadi objok kegiatan. Dan bentuk inilah yang terbanyak digunakan dalam Al-Quran.

Dalam pandangan Al-Quran, uang merupakan modal serta salah satu faktor produksi yang penting, tetapi "bukan yang terpenting". Manusia menduduki tempat di atas modal disusul sumber daya alam. Pandangan ini berbeda dengan pandangan sementara pelaku ekonomi modern yang memandang uang sebagai segala sesuatu, sehingga tidak jarang manusia atau sumber daya alam dianiaya atau ditelantarkan.

Menurut hasil perhitungan M. Quraih Shihab, bentuk pertama ditemukan sebanyak 23 kali, sedang bentuk kedua sebanyak 54 kali. Dari $63-65$

${ }^{4}$ V. Wiratna Sujarweni, Manajemen Keuangan, (Yogyakarta: PT. Pustaka Baru, tt), 
jumlah ini yang terbanyak dibicarakan adalah harta dalam bentuk objek, dan ini memberi kesan bahwa seharusnya harta atau uang menjadi objek kegiatan manusia. Kegiatan tersebut adalah aktivitas ekonomi.

Modal tidak boleh diabaikan, manusia berkewajiban menggunakannya dengan baik, agar ia terus produktif dan tidak habis digunakan. Karena itu seorang wali yang menguasai harta orang-orang yang tidak atau belum mampu mengurus hartanya, diperintahkan untuk mengembangkan harta yang berada dalam kekuasaannya itu dan membiayai kebutuhan pemiliknya yang tidak mampu itu, dari keuntungan perputaran modal, bukan dari pokok modal. Ini dipahami dari redaksi surat Al-Nisa' (4): 5, yaitu:

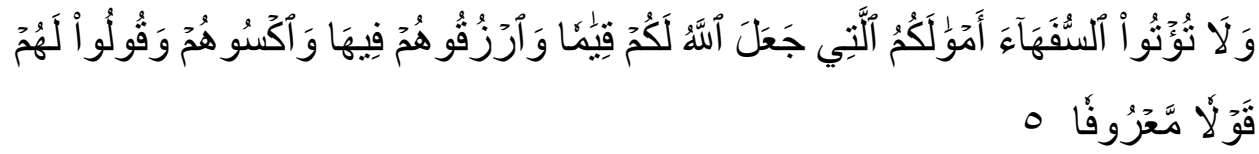

"Dan janganlah kamu serahkan kepada orang yang belum sempurna akalnya, harta (mereka yang dalam kekuasaan) kamu yang dijadikan Allah sebagai pokok kehidupan. Berilah mereka belanja dan pakaian (dari hasil harta itu) dan ucapkanlah kepada mereka perkataan yang baik." (QS. An-Nisa': 5)

Dinyatakan Warzuquhum fiha bukan Warzuquhum minha. "Minha" artinya "dari modal", sedang "fiha" berarti "di dalam modal", yang dipahami sebagai ada sesuatu yang masuk dari luar ke dalam (keuntungan) yang diperoleh dari hasil usaha. Karena itu pula modal tidak boleh menghasilkan dari dirinya sendiri, tetapi harus dengan usaha manusia. Ini salah satu sebab mengapa membungakan uang, dalam bentuk riba dan perjudian, dilarang oleh Al-Quran. Salah satu hikmah pelarangan riba, serta pengenaan zakat sebesar 2,5\% terhadap uang (walau tidak diperdagangkan) adalah untuk mendorong aktivitas ekonomi, perputaran dana, serta sekaligus mengurangi spekulasi serta penimbunan.

Bagi pemilik uang yang tidak atau kurang mampu mengelola uangnya, para ulama mengembangkan cara-cara yang direstui oleh AlQuran dan Sunnah Nabi, antara lain melalui apa yang dinamai murabahah, mudharabah atau musyarakah. Murabahah adalah pembelian barang menurut rincian yang ditetapkan oleh pengutang, dengan keuntungan dan waktu pembayaran yang disepakati. Mudharabah adalah bergabungnya 
tenaga kerja dengan pemilik modal, sebagai mitra usaha dan keuntungan yang dibagi sesuai rasio yang disepakati. Musyarakah adalah memadukan modal untuk bersama-sama memutarnya, dengan kesepakatan tentang rasio laba yang akan diterima. ${ }^{5}$

\section{Sumber Pemasukan dan Anggaran Pengeluaran}

1. Pemasukan

Ibnu Sina berpendapat mengenai sumber pemasukan, yaitu Sesungguhnya rezeki kekayaan yang cukup merupakan perhiasan hidup yang paling indah bagi manusia, tetapi tergantung pada berhak tidaknya ia terhadap kekayaan tersebut. Jika cara mengusahakan kekayaan itu tepat, barulah ia mendapatkan kekayaan hidup, dan keindahan itu semakin bertambah manakala caranya, sangat akrab dan paling menepati hukum. Adapun cara usaha yang paling tepat ialah melakukan usaha menurut cara yang paling bersih, suci, dan jauh dari sifat tamak dan rakus, dan jauh dari loba yang keji dan kotor. Apabila terjadi sebaliknya, rezeki kekayaan itu akan kehilangan keindahannya, bahkan menjadi keji.

Sesungguhnya segala kekayaan yang diperoleh dengan paksaan, kesombangan, kekerasan, dan bujukan, tidaklah sah untuk dinamakan kebaikan. Begitu juga keuntungan/laba yang didapat dengan jalan dosa dan aib, dan membawa pada sebutan-sebutan yang jelek dan pencakapan yang tidak pantas adalah keuntungan/laba yang tidak bernilai. Jalan yang demikian sebaiknya dijauhi. Sering terjadi, kekayaan diperoleh dengan menjatuhkan air muka dan merendahkan hidup, dan akibatnya mencemarkan nama dan mengotori kehormatan. Tidak disangsikan lagi bahwa baik jalan ini maupun jalan di atas, keduanya menjadikan merosotnya keuntungan/laba tersebut dan menodai kesuciannya. ${ }^{6}$

\footnotetext{
${ }^{5}$ M. Quraih Shihab, Wawasa al-Qur'an, (Bandung: Mizan, 1996), 411-412

${ }^{6}$ Abdullah Zaky Al Kaaf, Ekonomi Dalam Perspektif Islam, 180
} 
Oleh karena itu, penilaian yang paling pantas dipakai terhadap sesuatu usaha, yaitu bagaimana cara mendapatkannya, jadi bukan berapa tinggi harganya dan berapa banyak jumlah barangnya karena harga dan banyaknya itu akan merosot kalau menggunakan cara yang tidak baik. Hakikat yang sebenarnya adalah segala rezeki kakayaan yang halal serta bersih dari dosa tentu lebih sedap untuk dinikmati, lebih menyenangkan, lebih besar berkahnya, dan lebih bersih penggunaannya, meskipun jumlahnya sedikit dan harganya/timbangannya rendah.

Untuk pengaturan anggaran, Ibnu Sina menganjurkan penghitungan anggaran secara cermat, baik mengenai pemasukan maupun pengeluarannya. Terhadap pengeluaran yang tidak wajib, setiap orang harus bersikap hati-hati agar tidak terjadi pengeluaran uang yang percuma. Pengeluaran wajib adalah:

a. Nafkah, yaitu segala perongkosan yang diperlukan bagi hidupnya, misalnya perumahan, pakaian, makanan, belanja rumah tangga, biaya pendidikan, dan lain-lain.

b. Amal kebajikan, yaitu segala perbuatan amal untuk orang lain, baik masyarakat maupun negara. ${ }^{7}$

2. Pengeluaran

a. Pengeluaran konsumtif harus dikeluarkan sehemat mungkin.

Dalam persoalan perbelanjaan hidup sehari-hari (yang bersifat konsutif), haruslah diperhatikan beberapa syarat dalam pengeluarannya, yaitu pada jalan yang benar dan jauh dari keborosan dan kesesatan. Jalan benar yang demikian adalah sederhana dan hemat dalam segala perbelanjaan. Harus dijauhi pembelian yang tidak perlu. Haruslah berdiri di tengah-tengah antara royal dan kikir, antara pemborosan dan kikir. ${ }^{8}$

b. Pengeluaran untuk masyarakat dan negara

${ }^{7}$ Abdullah Zaky Al Kaaf, Ekonomi Dalam Perspektif Islam, 182

${ }^{8}$ Abdullah Zaky Al Kaaf, Ekonomi Dalam Perspektif Islam, 183 
Di samping perongkosan yang dinamakan nafkah, adalah kewajiban lain di antaranya adalah:

1) Zakat, yaitu pengeluaran wajib dari kekayaan, baik berupa kekayaan diri seperti emas dan perak, uang atau berupa kekayaan perusahaan, seperti hasil-hasil pertanian, peternakan, perdagangan dan lain-lain.

2) Sedekah, yaitu pengeluaran yang amat mulia untuk membantu fakir miskin atau usaha-usaha sosial lainnya, misalnya akibat bencana alam, kelaparan, dan sebagainya.

3) Amal kebajikan, yaitu bantuan secara umum, yang diberikan kepada semua orang atau segala badan yang memerlukannya. ${ }^{9}$

\section{E. Tafsir Surah Yusuf Ayat 47-48}

Perspektif zaman nabi Yusuf as. dalam hal menabung, terlihat pada redaksi ayat-ayatnya menabung secara makro (tugas negara). Walaupun makro, ini dapat diterapkan secara mikro (individu). Berikut QS. Yusuf ayat 47-48:

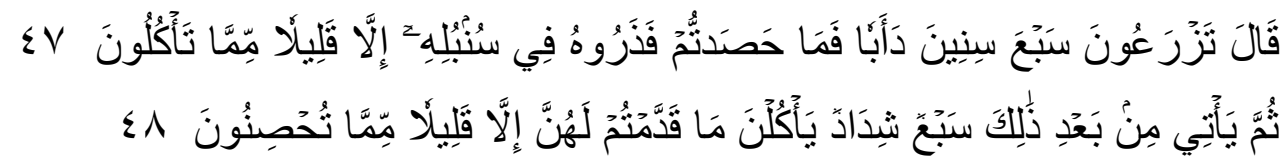

"Dia berkata, "Kamu bercocok tanam tujuh tahun sebagaimana biasa, maka apa yang kamu tuai hendaklah kamu biarkan di bulirnya kecuali sedikit untuk kamu makan. Kemudian, sesudah itu akan datang tujuh yang amat sulit, yang menghabiskan apa yang amat sulit, yang menghabiskan apa yang kamu simpan untuk menghadapinya kecuali sedikit dari apa yang kamu simpan”. ( QS. Yusuf: 47-48)

Mendengar pertanyaan yang diajukan atas nama raja dan pemukapemuka masyarakat itu, tanpa menunggu seusai dengan harapan penanya langsung saja dia, yakni Nabi Yusuf as., berkata seakan-akan berdialok dengan mereka semua. Karena itu, beliau menggunakan bentuk jamak, "Mimpi memerintahkan kamu, wahai masyarakat Mesir, melalui raja, agar

\footnotetext{
${ }^{9}$ Abdullah Zaky Al Kaaf, Ekonomi Dalam Perspektif Islam, 186
} 
kamu terus menerus bercocok tanam selama tujuh tahun sebagaimana biasa kamu mercocok tanam, yakni dengan memperhatikan keadaan cuaca, jenis tanaman yang ditanam, pengairan dan sebagainya atau selama tujuh tahun berturut-turut dengan bersungguh-sungguh. Maka apa yang kamu tuai dari hasil panen sepanjang masa itu hendaknya kamu biarkan di bulirnya agar dia tetap segar tidak rusak karena biasanya gandum Mesir hanya bertahan dua tahun demikian pendapat pakar tafsir Abu Hayyan. Kecuali sedikit yaitu yang tidak perlu kamu simpan dan biarkan di bulirnya yaitu yang kamu butuhkan untuk kamu makan. Kemudian, sesudah masa tujuh tahun itu, akan datang tujuh tahun yang amat sulit akibat terjadinya paceklik di seluruh negeri yang menghabiskan apa yang kamu simpan untuk menghadapinya, yakni untuk menghadapi tahun sulit itu yang dilambangkan oleh tujuh bulir gandum yang kering itu kecuali sedikit dari apa, yakni bibit gandum, yang kamu simpan. Itulah takwil mimpi raja.

Nabi Yusuf as. memahami tujuh ekor sapi sebagai tujuh tahun masa pertanian. Boleh jadi, karena sapi digunakan membajak, kemudian sapi adalah lambang kesuburan, sedang sapi kurus adalah masa sulit di bidang pertanian, yakni masa paceklik. Bulir-bulir gandum lambang pangan yang tersedia. Setiap bulir dengan setahun. Demikian juga sebaliknya.

Thabathabai pakar tafsir menilai bahwa mimpi tersebut adalah isyarat kepada raja untuk mengambil langkah-langkah guna menyelamatkan masyarakatnya dari krisis pangan. Yaitu hendaklah dia mengemukakan tujuh ekor sapi agar dimakan oleh sapi kurus dan menyimpan sebagian besar dari bahan pangan yang telah dituai tetap dalam bulirnya agar tetap segar dan tidak rusak oleh faktor cuaca dan sebagainya. Dengan demikian, Nabi Yusuf as menyampaikan apa yang akan terjadi dan bagaimana menghadapinya, yaitu hendaklah bersungguh-sungguh menanam serta menyimpan sebagian besar hasil panen. ${ }^{10}$

${ }^{10}$ M. Quraish Shihab, Tafsir al-Mishbah, (Jakarta: Lentera Hati, 2009), 111-112, 
Keterangan atas QS Yusuf ayat 47-48 ada pada ayat-ayat sebelumnya sebagai latar belakangnya. Dijelaskan mulai dari ayat 43 hingga 46, bahwa raja pada suatu ketika bermimpi yang sangat ajaib sekali dan sangat mengelisahkan hatinya. Belum pernah raja bermimpi seperti itu selama hidupnya. Maka dikumpulkannya semua orang cerdik pandainya, juru-juru tenun dan pembesar-pembesar kerajaannya, lalu raja berkata,

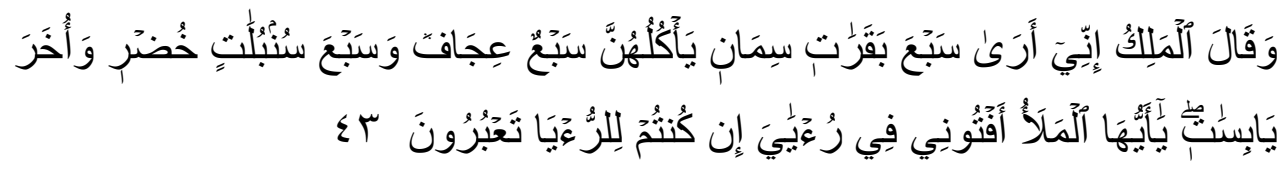

Raja berkata, " Sesungguhnya aku bermimpi melihat tujuh ekor sapi betina yang gemuk-gemuk dimakan oleh tujuh yang kurus-kurus, dan tujuh bulir-bulir hijau dan yang lain kering-kering, Wahai, orangorang yang terkemuka! Terangkanlah kepadaku tentang takwil mimpiku itu jika kamu dapat menakwilkan mimpi. "Mereka menjawab, Itu adalah mimpi-mimpi yang kosong dan sekali-kali bukanlah kami menyangkut penakwilan mimpi-mimpi kosong orangorang yang ahli. (QS. Yusuf: 43)

Ternyata, tidak seorang pun dari mereka yang dapat memberikan tabir mimpi raja itu. Kemudian ada tukang siram kebun raja yang memberitahukan seorang pemuda yang berada di dalam penjara mempunyai kedalaman ilmu, Yusuf namanya. Raja pun mengutus tukang siram kebun itu menemui Yusuf. Saat bertemu dengan Yusuf, tukang siram kebun menayakan perihal mimpi raja. Karena itu, dalam QS Yusuf ayat 47 tersebut di atas. Yaitu untuk bertanam tujuh tahun lamanya seperti biasanya. Maka apa yang sudah kamu panen biarkan tetap saja ditangkainya, kecuali sedikit untuk dimakan yaitu untuk cadangan makanan ketika datang masa sulit selama tujuh tahun. Dan Yusuflah yang berhasil menerangkan tabir mimpi raja itu dengan jelas dan benar. Inilah prinsip yang menjelaskan pentingnya menyisihkan harta pada saat berkelimpahan untuk digunakan pada saat kekurangan. ${ }^{11}$

\section{F. Tafsir Surah Yusuf ayat 58-61}

${ }^{11}$ Dwi Suwikyo, Ayat-Ayat Ekonomi, 178-179 


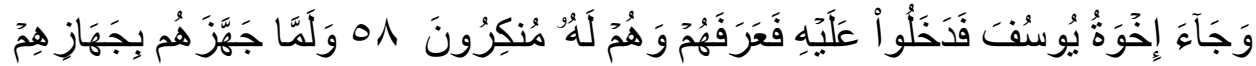

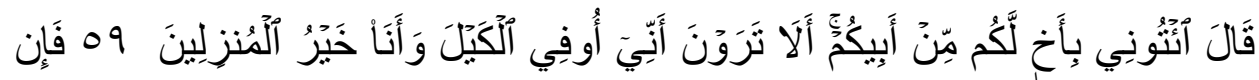

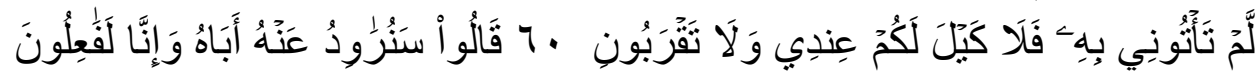

"Dan datanglah saudara-saudara Yusuf, lalu mereka masuk kepadanya, maka, dia langsung mengenal mereka, sedang mereka terhadapnya benar-benar asing. Dan tatkala dia menyiapkan untuk mereka bahan makanan mereka, dia berkata, "Bawalah saudaramu kepadaku saudara kamu yang seayah dengan kamu,. Tidaklah kamu melihat bahwa aku menyempurnakan sukatan dan aku adalah sebaik-baik penerima tamu? Jika kamu tidak membawakan kepadaku, maka kamu tidak akan mendapat sukatan lagi dariku dan janganlah kamu mendekatiku, "Mereka berkata, "Kami akan membujuk ayahnya dan sesungguhnya kami benar-benar akan menjadi pelaksana-pelaksana" (QS Yusuf: 5861)

Waktu berjalan lama. Kini mimpi raja terbukti dalam kenyataan. Masa paceklik melanda daerah Mesir dan sekitarnya. Ya'kub as. beserta anakanaknya yang tinggal tidak jauh dari Mesir, yakni di Palestina. Mengalami juga masa sulit. Mereka mendengan bahwa di Mesir pemerintahannya membagikan pangan untuk orang-orang butuh atau menjualnya dengan harga yang sangat murah. Agaknya jatah itu bersifat perorangan. Karena itu, Ya'kub as. memerintahkan semua anaknya menuju ke Mesir, kecuali Benyamin / saudara kandung Yusuf as.

Ayat-ayat di atas mengesankan bahwa Yusuf as. terlibat langsung serta aktif dalam upaya pembagian makanan dan pengawasannya, tidak melimpahkan pekerjaan itu kepada bawahannya. Ini terbukti dari pertemuannya dengan saudara-saudaranya di lokasi pembagian itu serta masuknya mereka untuk menemuinya di tempat tersebut. Apa yang dilakukan Yusuf as. ini menunjukkan betapa besar tanggung jawab beliau. Dan itu juga merupakan pelajaran yang sangat berharga bagi siapa pun dalam menjalankan tugas. ${ }^{12}$

\section{G. Kiat-Kiat Untuk Menabung} Vol. 6

${ }^{12}$ M. Quraish Shihab, Tafsir al-Mishbah, (Jakarta: Lentera Hati, 2009), 137-139, 
1. Berprinsip hidup hemat, hal ini meliputi hemat dalam makanan, minuman, dan segala macam kebutuhan untuk tidak berlebihan. Allah berfirman pada surah al-'Araf ayat 31:

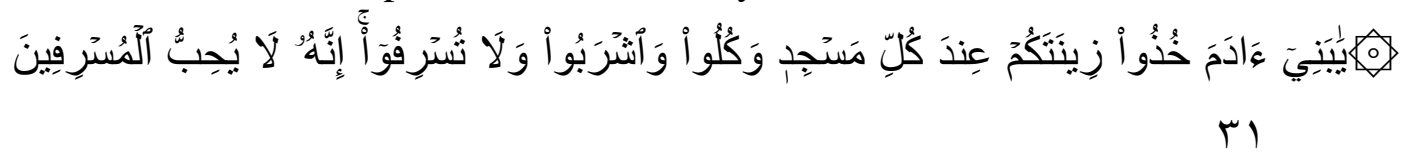

"Hai anak Adam, pakailah pakaianmu yang indah di setiap (memasuki) masjid, makan dan minumlah dan janganlah berlebihlebihan. Sesungguhnya Allah tidak menyukai orang-orang yang berlebih-lebihan” (QS. Al-“Araf: 31)

Penekanan ayat di atas adalah Kuluи wasyrabuu wa laa Tusrifuu Innahuu Laa Yuhibbul Musfrifiin (makan dan minumlah dan janganlah berlebih-lebihan. Sesungguhnya Allah tidak menyukai orang-orang yang berlebih-lebihan). Saat makan dan minum harus tetap bijak dengan tidak berlebih-lebihan. Sering kali rasa lapar dan haus menjadikan manusia terdorong untuk memuaskan dirinya sendiri. Mestinya lebih bijak dengan tidak berlebih-lebihan seperti membatasi makan dan minum sesuai dengan kebutuhan tubuh dan tidak pula melampaui batas-batas yang diharamkan. Jangan berlebihan dengan cara tidak benar dalam agama hanya karena hawa nafsu yang menyesatkan. Berlebih-lebihan merupakan perbuatan yang dapat merugikan manusia dalam jangka panjang. Sesungguhnya Allah tidak menyukai orang-orang yang berlebih-lebihan. ${ }^{13}$

Perintah makan dan minum, lagi tidak berlebih-lebihan, yakni tidak melampaui batas, merupakan tuntunan yang harus disesuaikan dengan kondisi setiap orang. Ini karena kadar tertentu yang dinilai cukup untuk seseorang, boleh jadi telah dinilai melampaui batas atau belum cukup buat orang lain. Atas dasar itu, kita dapat berkata bahwa penggalan ayat tersebut mengajarkan sikap proporsional dalam makan dan minum. Dalam konteks berlebih-lebihan ditemukan konsep Nabi Muhammad saw, "Tidak ada wadah yang dipenuhkan manusia lebih buruk dari perut. Cukuplah bagi putra-putri Adam beberapa suap yang

${ }^{13}$ Dwi Suwikyo, Ayat-Ayat Ekonomi, 151 
dapat menegakkan tubuhnya. Kalau pun harus (memenuhi perut), hendaklah sepertiga untuk makanannya, sepertiga untuk minumannya, dan sepertiga untuk pernafasannya. "(HR. At-Tirmidzi, Ibn Majah, dan Ibn Hibban melalui Miqdam Ibn Ma'dikarib). Ditemukan juga pesan yang menyatakan: "Termasuk berlebih-lebihan bila Anda makan apa yang selera Anda tidak tertuju padanya."14

Pemborosan dan sikap konsumtif dapat menimbulkan kelangkaan barang-barang yang dapat menimbulkan ketidakseimbangan akibat kenaikan harga-harga. Dalam rangka memelihara keseimbangan itu, Islam menugaskan Pemerintah untuk mengontrol harga, bahkan melakukan

langkah-langkah yang diperlukan untuk menjamin agar paling tidak bahan-bahan kebutuhan pokok dapat diperoleh dengan mudah oleh seluruh anggota masyarakat. ${ }^{15}$

2. Etos Kerja Yang Tinggi

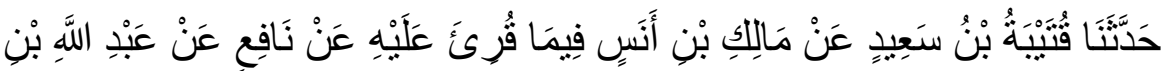

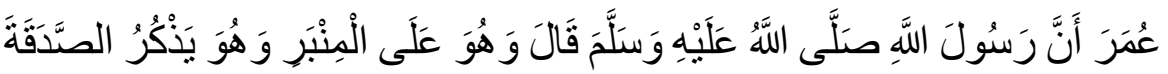

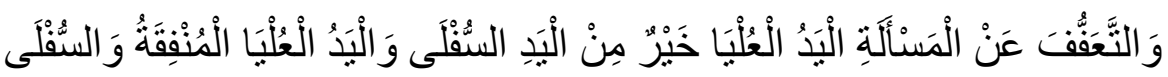

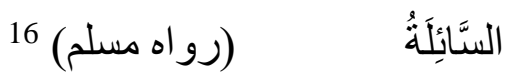

Telah mencritakan Qutaibah ibn Sa'id dari Malik ibn Anas dibacakan padanya dari Nafi' dari Abdullah ibn 'Umar sesungguhnya Rasulullah saw bersabda di atas mimbar beliau menyebut tentang sedekah dan menahan diri dari meminta-minta, sabda beliau: "Tangan yang di atas lebih baik daripada tangan yang di bawah. Tangan di atas adalah tangan pemberi, sementara tangan yang di bawah adalah tangan peminta-minta

${ }^{14}$ M. Quraish Shihab, Tafsir al-Mishbah, (Jakarta: Lentera Hati, 2009), 87-88, Vol.

${ }^{15}$ M. Quraih Shihab, Wawasan al-Qur'an, (Bandung: Mizan, 1996), 405.

${ }^{16}$ Muslim, Shahih Muslim, (Takhrij Hadis Digital, No Hadis 1715) 
Maksud hadis tersebut tidak berarti memperbolehkan memintaminta, tetapi memotivasi agar seorang muslim mau berusaha dengan keras agar dapat menjadi tangan di atas, yaitu orang yang mampu membantu dan memberi sesuatu pada orang lain dari hasil jerih payahnya. Bagaimana mungkin dapat membantu orang lain jika untuk memenuhi dirinya sendiri saja tidak mencukupi. Bagaimana mungkin dapat mencukupi kebutuhannya sendiri jika tidak mau berusaha keras. Seseorang akan dapat membantu sesama apabila dirinya telah berkecukupan. Seseorang dikatakan berkecukupan jika ia mempunyai penghasilan yang lebih. Seseorang akan dapat penghasikan lebih jika berusaha keras dan baik. Karenanya dalam bekerja harus disertai etos kerja tinggi. ${ }^{17}$

\section{H. Analisa}

Isyarat QS Yusuf ayat 47 terutama pada redaksi Fi Sumbulihi/tangkai. Sebuah isi pohon yang dibiarkan pada tangkainya dan disimpan akan lebih terjamin keamanannya. Jika buah tersebut di putus dari tangkainya lalu disimpan, keamanannya tidak kuat. Pelajaran yang tersirat dari metode penyimpanan buah yang tidak dilepas dari tangkainya. Yakni manusia menyimpan uang, tempat penyimpanan pun bermacam-macam. Ada yang berupa celengan dari kaleng/tanah liat, dompet yang disimpan di lemari, tabungan arisan, tabungan di bank, dan lain-lain. Misal nabung di bank sebesar Rp 1.000.000,- dan di celengan kaleng juga Rp 1.000.000,-. Pemilik tabungan tersebut jika akan mengambil yang di bank cenderung berfikir berkali-kali, karena rumitnya peraturannya. Berbeda dengan pemilik yang punya celengan kaleng ketika akan mengambil uangnya cenderung langsung di buka, karena tidak ada aturan yang rumit.

Pengeluaran yang bersifat wajib / konsutif sehemat mungkin untuk dianggarkan. Dengan kata lain penyimpanan lebih banyak di banding dengan pengeluarannya. Maka efeknya pada saat tidak ada sumber

\footnotetext{
${ }^{17}$ Ilfi Nur Diana, Hadis-Hadis Ekonomi, 202
} 
penghasilan, tabungan tersebut menjadi sumber penghasilannya. Digambarkan pada zaman Nabi Yusuf as. umatnya bekerja selama tujuh tahun dan penghasilannya untuk disimpan/ditabungkan lebih banyak daripada untuk kebutuhan pangan. Walhasil ketika paceklik selama tujuh tahun, masyarakat tidak mempunyai sumber penghasilan, kecuali peran/fungsi simpanan terdahulu bisa sebagai sumber penghasilan selama paceklik yaitu tujuh tahun.

Contoh gaji bulanan Rp 800.000,-. Separu darinya 400.000. yang disimpan minimal 450.000. anggaran buat nafkah 350.000 dalam satu bulan. Maka per hari $350.000: 30=11,666$ dibulatkan 11.650. ketika bulan berikutnya nganggur tetap bisa menganggarkan 11.650 per harinya.

Cerita pada zaman nabi Yusuf as. adalah menyinpan hasil bumi bukan mata uang. Disisi lain ada larangan menimbun barang. Kedua hal tersebut prakteknya sama, tetapi tujuannya berbeda. Yang dilarang adalah ada niat dan sengaja menimbun untuk mempermainkan harga/ mencari keuntungan yang sebesar-besarnya.

Islam melarang penimbunan atau hal-hal yang menghambat pendistribusian barang sampai ke konsumen. Menimbun adalah membeli barang dalam jumlah yang banyak kemudian menyimpannya dengan maksud untuk menjualnya dengan harga tinggi. Penimbunan dilarang agar harta tidak beredar hanya dikalangan orang-orang tertentu sebagaimana misi Islam. Sebuah hadis yakni:

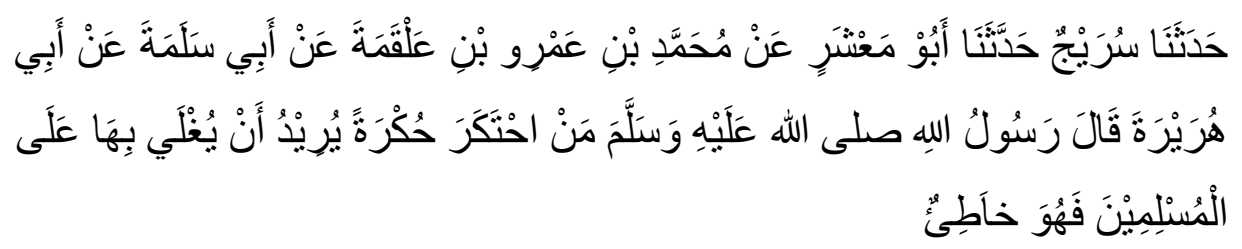

"Telah menceritakan Suraij telah menceritakan Abu Ma'syarin dari Muhammad Ibn Umar Ibn 'Alqamata dari Abi Salamah dari Abi Hurairah berkata, "Rasulullah telah bersabda: Siapa saja yang melakukan penimbunan untuk mendapatkan harga yang paling tinggi, dengan tujuan mengecoh orang Islam maka ternasuk perbuatan yang salah." 
Hadis tersebut mengisyaratkan bahwa perbuatan yang salah, yaitu menyimpang dari peraturan jual beli atau perdagangan dalam sistem ekonomi Islam yang berdasarkan al-Qur'an dan Hadis. ${ }^{18}$

Pada zaman kita (umat nabi Muhammad saw) berbeda dengan zaman nabi Yusuf as. umat nabi Muhammad saw selain pengeluaran biaya untuk kebutuhan konsutif juga pengeluaran harta yang bersifat wajib, seperti zakat mal dan fitrah, dan pergi Haji yang merupakan rukun Islam ke 5. Zaman nabi Yusuf as terlihat pada QS Yusuf ayat 47-48 pengeluaran biaya untuk pangan saja. Untuk penerapan metode tabungan zaman nabi Yusuf as diduga keras akan sulit. Titik tekan pada isyarat ayat di atas adalah menghemat kebutuhan pangan / konsutif lalu sisanya ditabungkan.

Analisa pada surah Yusuf ayat 58-61, bahwa fungsi penyimpanan hasil bumi selama 7 tahun di subsidikan / dibagikan kepada rakyat yang membutuhkan ketika benar-benar terjadi paceklik. Perekonomian waktu itu sangat mensejahterakan rakyat. Hal tersebut tak lepas dari sang pengaturnya yaitu Nabi Yusuf as. yang sangat pandai mengatur, merencanakan, mengalokasikan hasil bumi. Zaman sekarang dengan adanya keberadaan Bank, fungsi dan peranannya juga sangat mensejahterakan rakyat.

Menurut Ayun Sekar Widowati dalam sekripsinya yakni, Bank merupakan badan usaha yang menghimpun / meyimpan / mengumpulkan dana dari masyarakat dalam bentuk simpanan, dan menyalurkan kepada masyarakat untuk meningkatkan taraf hidup rakyat banyak. Apabila dilihat dari sejarahnya, kegiatan perbankan pada awalnya dimulai dari jasa penukaran uang (Kasmir, 2013: 27). Kegiatan operasional perbankan kemudian berkembang lagi menjadi tempat penitipan uang yang sekarang disebut dengan kegiatan simpanan. Uang yang disimpan oleh masyarakat pada bank dipinjamkan kembali kepada masyarakat yang membutuhkannya. Jasa-jasa bank lainnya menyusul sesuai dengan perkembangan zaman dan kebutuhan masyarakat yang semakin beragam. Perkembangan dunia perbankan di Indonesia cukup signifikan dari waktu ke waktu. Berdasarkan

${ }^{18}$ Ilfi Nur Diana, Hadis-Hadis Ekonomi, 64 
data Statistik Perbankan per Desember 2017, jumlah bank umum di Indonesia tercatat sebanyak 115 bank dengan jumlah kantor bank umum yang meningkat sebanyak 2.340 dari tahun 2012. ${ }^{19}$

\section{Kesimpulan}

Menabung adalah suatu program terencana mempunyai visi dan misi. Prinsip hemat harus diterapkan agar program tabungan sukses. Jenis barang untuk disimpan pada kajian tafsir QS Yusuf ayat 47-48 adalah buah / hasil bumi. Guna simpanan / tabungan tersebut sebagai sumber penghasilan untuk memenuhi kebutuhan masa paceklik di zaman nabi Yusuf as. Isyarat tersebut dapat diterapkan untuk menyimpan uang. Karena uang adalah alat tukar-menukar. Guna simpanan / tabungan tidak hanya untuk masa paceklik tetapi untuk investasi, biaya pendidikan tinggi, biaya darurat yang tak terduga, dan lain-lain. Lembaga keuangan seperti bank fungsinya pun bermacam-macam, salah satunya adalah dana untuk pembangunan ekonomi, hal ini mirip fungsi tabungan pada zaman nabi Yusuf as.

\section{Daftar Pustaka}

Muslim, Shahih Muslim, Takhrij Hadis Digital

Nur Diana, Ilfi, Hadis-Hadis Ekonomi, Malang: UIN Maliki Press, 2012

Shihab, M. Quraish, Tafsir al-Mishbah, Jakarta: Lentera Hati, 2009 , Wawasan Al-Qur'an, Bandung: Mizan, 1996

Sujarweni, V. Wiratna, Manajemen Keuangan, Yogjakarta: PT. Pustaka Baru, tt Suwikyo, Dwi, Ayat-Ayat Ekonomi, Yogyakarta: Pustaka Pelajar, 2010 Widowati, Ayun Sekar, Pengaruh Pengetahuan Produk Tabungan, Reputasi Bank, dan Persepsi Nasabah mengenai suku bunga simpanan terhadap keputusan menabung nasabah, Yogyakarta: Sekripsi, 2018

Zaky Al Kaaf, Abdullah, Ekonomi Dalam Perspektif Islam, Bandung: CV Pustaka Setia, 2002

19 Ayun Sekar Widowati, Pengaruh Pengetahuan Produk Tabungan, Reputasi Bank, dan Persepsi Nasabah mengenai suku bunga simpanan terhadap keputusan menabung nasabah, (Yogyakarta: Sekripsi, 2018), 1 